Game Online di Kalangan Remaja

\title{
PENGARUH KECANDUAN GAME ONLINE BAGI REMAJA \\ TERHADAP KUALITAS TIDUR
}

\author{
Anita Laki Mbatu \\ 2171B0004 \\ S-I Administrasi Rumah Sakit \\ IIK STRADA Inodesia \\ Anitambatu12@gmail.com
}

\begin{abstract}
Abstrak
masa remaja adalah masa dimana seorang individu mengalami peralihan dari satu tahap ke tahap berikutnya dan mengalami perubahan baik emosi, tubuh, pola perilaku, dan juga penuh dengan masalah-masalah serta remaja cenderung memiliki rasa ingin tau yang besar. Game online merupakan suatu fenomena yang sedang marak di Indonesia termasuk di kalangan remaja. Fasilitas yang ada pada game online memberikan suatu kemudahan yang dapat menjadikan remaja cenderung menjadi lebih asik dan menjadi sibuk dengan game online yang dimainkan. Banyak yang beranggapan bahwa dengan bermain game online dapat menghilangkan stress. Nanum hal tersebut tidak dibenarkan karena ketika secara terus menerus dimainkan maka akan mengakibatkan kecanduan yang dapat berujung pada gangguan kesehatan terutama pada kualitas tidur dan juga mengganggu kegiatan lainnya.
\end{abstract}

Kata kunci: Game Online, Remaja, kecanduan

\section{Latar Belakang}

Masa remaja adalah masa dimana seorang individu mengalami peralihan dari satu tahap ke tahap berikutnya dan mengalami perubahan baik emosi, tubuh, pola perilaku, dan juga penuh dengan masalah-masalah serta remaja cenderung memiliki rasa ingin tau yang besar. Masa remaja awal berada pada umur 12-16 tahun masa tersebut individu banyak mengalami perubahan, meliputi perubahan pada fisik, mental, emosional, serta sosial. Perubahan-perubahan itu cenderung membuat remaja mengalami kesulitan dalam menyesuaikan diri. Remaja seringkali menampilkan perilaku-perilaku yang buruk salah satunya adalah dampak dari kecanduan bermain game online atau bahkan menyimpang dari norma. (Depkes RI, 2009). Permainan game online merupakan suatu fenomena yang sedang marak di Indonesia termasuk di kalangan remaja atau anak sekolah. Fasilitas yang ada pada game online memberikan suatu kemudahan yang dapat menjadikan siswa/siswi cenderung menjadi lebih asik dan menjadi sibuk dengan game 
online yang dimainkan. Hal itu tentunya sangat mempengaruhi semua aktifitas sehari-hari termasuk kualitas tidur, gaya hidup dan interaksi sosialnya. Game online juga memberikan hiburan tetapi juga dapat memberikan tantangan yang juga menarik untuk dapat diselesaikan sehingga seseorang yang bermain game online tanpa harus memperhitungkan waktu untuk mencapai kepuasan. Hal ini menjadikan seorang "Gamer" tidak hanya menjadi penikmat tetapi menjadi seorang pecandu Game online. ( Pratiwi, 2012) American Medical Association menyatakan bahwa pada tahun 2007 terdapat $90 \%$ remaja di Amerika bermain game online dan $15 \%$ atau lebih dari 5 juta remaja mengalami kecanduan game online, sedangkan di China pada tahun 2007 terdapat $10 \%$ atau 30 juta remaja 3 yang mengalami kecanduan game online (Young, 2009). Pada tahun 2010 di Indonesia terdapat 50\% jumlah pengguna game online yang dinyatakan detiknet melalui situs resmi game online Indonesia, dimana pengguna game online banyak diminati di kalangan pelajar dan mahasiswa (Hariyanto, 2009). Dari penjabaran di atas dapat disimpulkan bahwa pengguna game online di dalam negeri maupun luar negeri adalah remaja.

\section{Kasus/Masalah}

Rumah Sakit Jiwa Jawa Barat menangani 100 pasien kecanduan game sepanjang Januari hingga November 2019. Rata-rata setiap bulan ada 10 pasien yang ditangani.

Kepala Instalasi Kesehatan Jiwa dan Remaja Rumah Sakit Jiwa Jawa Barat,
Lina Budianti kepada Kompas.com, Rabu (18/12/2019) mengatakan pasien yang ditangani rata-rata berusia remaja antara 15-17 tahun. Bahkan ada satu pasien yang masih berusia 3,5 tahun. RSJ Jabar Terus Bertambah Dilansir dari pemberitaan Kompas.com pada 29 November 2019, psikiater Rumah Sakit Jiwa Provinsi Jawa Barat, Ade Kurnia Surawijaya mengatakan kecanduan game atau gawai bisa mengganggu fungsi personal seperti mengganggu belajar, pekerjaan, dan aktivitas umum lainnya. Ia mengatakan pasien kecanduan game online butuh konseling bila telah lupa waktu, sulit konsentrasi, dan antisosial.

\section{Tinjauan pustaka}

Pengertian game adalah aktivitas yang dilakukan untuk fun atau menyenangkan yang memiliki aturan sehingga ada yang menang dan ada yang kalah. Selain itu, game membawa arti 17 sebuah konteks, fisik atau mental, menurut aturan tertentu, untuk hiburan, rekreasi, atau untuk menang taruhan. Game online adalah permainan yang dapat diakses oleh banyak pemain, dimana mesinmesin yang digunakan pemain dihubungkan oleh internet.

1. Faktor-faktor yang mempengaruhi kecanduan game online.

a. Faktor Internal Faktor internal adalah suatu penyebab yang dialami oleh seorang anak berdasarkan dari dorongan dalam dirinya sebagai contoh adalah seseorang yang bosan cenderung ingin bermain game sebagai bentuk pengalihan perhatian dan ketertarikan seseorang yang 
tertarik dengan permainan virtual cenderung lebih sering bermain daripada yang tidak.

b. Faktor Eksternal Faktor eksternal berasal dari luar diri individu sebagai contoh adalah Life stressful events adalah seseorang yang memiliki beban atau tekanan hidup memilih bermain game sebagai bentuk pengalihan dan komunitas game yaitu orang yang termasuk dalam komunitas game akan lebih mudah untuk mendapatkan informasi mengenai game-game terbaru sehingga seseorang cenderung ingin mencoba dan mencoba terus.

2. Aspek-aspek perilaku kecanduan game online

Perilaku kecanduan game online dapat disebabkan oleh ketersediaan dan bertambahnya jenis-jenis game di pasaran yang semakin pesat sejajar dengan perkembangan teknologi. Kecanduan permainan ini dapat digolongkan dalam beberapa kategori yakni:

a. Kegagalan yang berulang-ulang dalam mengontrol suatu perilaku (ketidakmampuan untuk mengontrol),

b. Berlanjutnya suatu perilaku yang berulang-ulang dan menimbulkan dampak yang negatif.

\section{Pembahasan}

A. Pengertian Game Online

Pengertian game adalah aktivitas yang dilakukan untuk fun atau menyenangkan yang memiliki aturan sehingga ada yang menang dan ada yang kalah. Selain itu, game membawa arti 17 sebuah konteks, fisik atau mental, menurut aturan tertentu, untuk hiburan, rekreasi, atau untuk menang taruhan. (Macmillan, 2011). Game online adalah permainan yang dapat diakses oleh banyak pemain, dimana mesin-mesin yang digunakan pemain dihubungkan oleh internet. Game online merupakan aplikasi permainan yang berupa petualangan, pengaturan strategi, simulasi dan bermain peran yang memiliki aturan main dan tingkatan-tingkatan tertentu. Bermain game online membuat pemain merasa senang karena mendapatkan kepuasaan psikologis.

B. Dampak perilaku kecanduan game online

Menunjukkan sikap yang antisosial. Sementara itu, dari sisi kesehatan, seringkali mengalami gangguan tidur sehingga mempengar uhi sistem metabolisme tubuhnya, sering merasa lelah (fatigue syndrome), kaku leher dan otot, hingga Karpal Turner Syndrome. Seseorang dapat Terus menerus memikirkan kegiatan bermain video game dan tidak dapat berkonsentrasi dengan apa yang sedang dilakukan nya. Bahkan setiap pembicaranya pu n selalu berkisar-perilaku, tindakan, dan topik seputar video game.

\section{Kesimpulan}


Hampir semua Remaja di Indonesia telah menjadikan game online sebagai hal yang dapat menghilangkan stress dan sebagai aktifitas biasa sedangkan bahaya game online dapat berdampak buruk bagi kesehatan terutama pada kualitas tidur. Dorongan untuk berhenti bermain game online untuk remaja yaitu niat dari diri sendiri dan juga dorongan dari orang lain. Yang bisa dilakukan adalah dengan melakukan penyuluhan tentang bahaya kecanduan game online. Kalau tidak dihentikan sejak dini akan berdampak buruk di hari depan nanti.

\section{Daftar Pustaka}

Adams, E., Rollings, A. (2007). Fundamentals of Game Design. Prentice Hallhttp://www.designersnotebook.c om/Books/Fundamentals_of_Game _Design/fundamentals_ch21.pdf.

Agustina, H. (2009). Psikologi perkembangan. Bandung : PT. Refika Aditama.

Ameliya, R. (2008). Pelatihan asertif untuk mereduksi perilaku adiksi online game pada remaja. Diperoleh tanggal 17 Oktober 2017 dari http://repository.upi.edu/operator/upl oad/s_ppb_044802_chapter2.p df.

Ananda, W. (2018). Hubungan Kecanduan Game Online Dengan Gangguan Pola Tidur Pada Mahasiswa Program Studi Ilmu Keperawatan Angkatan 2012 di Universitas
Tribhuwana Tunggadewi Malang. Jurnal Ilmiah. Vol 3 No.2.

Arikunto, S. (2010). Prosedur Penelitian Suatu Pendekatan Praktek. Jakarta : Rineka Cipta.

Asmadi. (2008). Konsep Dasar Keperawatan. Jakarta : EGC.

Atkins, S. (2017). Langkah Pertama Melalui Insomnia. Jakarta : Libri

Chandra, A. N. (2006). Gambaran perilaku dan motivasi pemain online games. Jurnal Pendidikan Penabur No.07/Th.V/Desember 2006, p. $1-11$.

Depkes RI. 2009. Sistem Kesehatan Nasional. Jakarta. Diakses pada tanggal 20 Oktober 2017 dari https://www.scribd.com/doc/162685 921/usiamenurut-depkes.

Febriandari, dkk (2016). Hubungan Kecanduan Bermain Game Online Terhadap Identitas Diri Remaja. Jurnal Keperawatan Jiwa Vol.4 No.1. Universitas Riau.

Freeman, C. B. (2008). Internet gaming addiction. Journal for Nurse Practitioners, vol. 4,1, 42-47.

Hariyanto, A. (2009). Membuat Anak Cepat Pintar Membaca. Jogjakarta : Diva Press. 